pest). 'Tho late Dr. M. A. Eillison succeoded J)r. Brück as senior professor in the Astronomical Section, and the present senior professor is Dr. P. A. Wayman, formerly of the Royal Greenwich Observatory. Dr. Janossy was succeeded by Dr. Cormae Ó Ceallaigh as senior professor in the Cosmic Ray Section, and $\mathrm{Mr}$. 'Thomas Murphy succeoded Dr. Pollak as senior professor in the Geophysical Section. A duty laid down for all constituent schools is the training of advanced, students in methods of modern rosearch, and scholars from all five continents have studied at the Institute. The extent and quality of the research carried out in the Schools can be assessed by reference to the works published by members of the staff and the numerous papers by both staff and scholars which have been published in leading scientific journals and periodicals. An informal celebration of the silver jubilee was held in the Royal Irish Academy, Dublin, on November 16, at which the President of Ireland, Mr. de Valéra, who us Prime Minister' was responsible for the setting up of the Institute, was the guest of honour.

\section{Journal of Zoology}

THE Proceedings of the Zoological Society, now published as the Joumal of Zoology, boing the Proceedings of the 7oological Socicty of London, publishes papers on all aspects of zoology, including systematics. In particular, it aims at publishing papers on the more general aspects of biology which do not fall within the province of the more specialized journals. The Journal has recently increased its number of pages and is able to accept papers of rather more than usual length, although, of course, it in no way encourages prolixity, and places quality before quantity. Traditionally the Journal specialized in systematic and morphological subjects; but it has now widoned its scope to be a true journal of zoology, and a glance at the issues for recent years shows that ecological, physiological and ethological papers are now included, dealing with all phyla of the animal kingdom. Papers are published by workers in universities and research institutions from all parts of the world, provided they are of sufficient standard.

\section{Journal of Cell Science}

THE Quarterly Journal of Microscopical Science--one of the oldest British biological journals-is changing its title to Journal of Cell Science, with effect from 1966. It has for many years been publishing work on cells, being, in fact, one of the few journals in Britain to do so. The decision to concontrate exclusively on cytology was taken three years ago, and since that time the proportion of papers on histological and micro-anatomical topies, which at one time figured prominently in its pages, has gradually been reduced. The Journal of Cell Science will deal with the study of coll organization in all its aspects, publishing papers on the structure and functions of cells at all lovols of analysis and including material on such topics as cell growth and division, cell movements and interactions, and cell genetics. Contributions on microorganisms and viruses will be accepted, in so far as they are relevant to an understanding of cell organization, and accounts of new techniques will be published. The journal is to have a new format and page size and will be pub. lished by the Cambridge University Press. The editors, Prof. H. G. Callan and Dr. A. V. Grimstone, will in future be assisted by an editorial board. The volume of research on cell biology in Britain is steadily increasing, and the need for a wide-ranging journal in this field has been felt for some time. It seems likely that the Journal of Cell Science will go far towards filling this noed.

\section{The Soils on Quaternary Beach Ridges in South Australia}

Calcareous beach sands are found in some thirty ridges about 50-100 ft. high, running sub-parallel to and up to 60 miles inland from the coast of the south-east of
South Australia. 'Ihe soils derived from these sands and from estuarine and lacustrine deposits are the subject of an intorosting study by G. Blackburn, R. D. Bond and. A. R. P. Clarke entitled Soil Development Associated with Stranded Beach Ridges in South-east South Australia (Australia: C.S.I.R.O. Soil Publication No. 22, With an Appendix by N.H.Ludbrook. Pp. $66+4$ maps. Melbourne: C.S.I.R.O., 1965). The genotic status of the soil horizons has becn established by the cumulative size-frequency distributions of the sand fractions $(0.02-2.00 \mathrm{~mm})$ and detailed consideration is given to the problem of accounting for the diversity of the main soil types in a region where the present climatic variation cannot be a major factor. The quaternary calcareous beach sands are not of aeolian origin but may occur as flat-bedded layers or as massive coastal dunes; the absolute ages of the ridges have not been determined, but it is probable that they have resulted from upwarping and from glacial-eustaticsea-level changes. The four soil types described are: (1) podzols, characteristic of those in other parts of the world; (2) terra rossa which are not developed directly from hard limestone; (3) ground-water rendzinas which aro variable in profile features; and (4) solodized solonetz which may display the morphological features commonly described but sometimes resemble the solonetz.

\section{Coal Petrology}

THE petrography of coal has had a long, chequered and controversial history of technical evolution, largely because different investigators over the year's have adopted different techniques in examining, identifying, describing, and reducing to a universally accepted philosophical classification, optically distinguishable entities in coals. Most coals derive from plant accumulation in swamps; remnants of these plants are observed in coals, but were undoubtedly much altered during geological time by periods of compression and thermal conditions caused by blanketing under later sediments. Different parts of original plants have altered in different ways; thus, mieroscopical examination tends to show varying optical properties from point to point, often in the same thin coal section. With high magnifications, fow areas of coal sections are seen to be homogeneous; with low magnifications, even visual examination, most coals reveal distinct layering of apparently similar materials. These are some of the practical difficulties encountered in petrographic investigations of coals, throughout the range of brown coal to anthracite. But despite this, in alliance with chemical, physical and technological examinations, petrological evaluations of coals have become an increasingly popular and valued tool both in coal research and industry. This is the theme of an excellent paper by C. F. K. Diessel and T. G. Callcott, entitled "Petrographic Features of New South Wales Coking Coals" (The B.H.P. Technical Bulletin, 23, 9, No. 2; August 1965. The Broken Hill Proprietary Co., Ltd., Melbourno, Australia). Although the purport of this paper is an appraisal of the petrographic and chemical composition of New South Wales coking coals, its value goes far beyond this, in that it oxamines contemporary systems of coal petrology now in vogue internationally and pin-points the still existing difficultios in the nomenclatures involved, despite the valuable publication of the International Handbook of Coal Petrology, 1963. This present paper includes a table of five differont but co-related systems of nomenclature in coal petrology (macerals); these are: Thiesson-U.S. Bureau of Mines; B.H.P. System as used at present; Geological Institute of the Academy of Science, U.S.S.R.; Spackman System; and the Stopos-Heerlen System. As the authors remark, conversion from one of these systems to another is by no means a simple matter; apart from different techniques used in analysis, widely differing points of view prevail on the essentials of a descriptive basis for coals. The problems facing the International 